\title{
LEVERAGING THE SYNERGY BETWEEN ANTIMICROBIAL STEWARDSHIP AND INFECTION PREVENTION AND CONTROL IN FIGHTING ANTIMICROBIAL RESISTANCE
}

\author{
Massimo Sartelli ${ }^{1,2}$ \\ ${ }^{1}$ Department of Surgery, Macerata Hospital, Macerata, Italy \\ ${ }^{2}$ Global Alliance for Infections in Surgery
}

Primljen/Received 09. 09. 2021. god.

Abstract: The COVID-19 pandemic had a great impact on the understanding of both antimicrobial stewardship (AS) and infection prevention and control (IPC).

During the COVID-19 pandemic, the collaboration between AS and IPC has mitigated the shortcomings experienced by health systems around the world, enhancing the performance of both, reinforcing the synergy between them, and increasing their preparedness in fighting antimicrobial resistance.

In planning the post-pandemic era, health systems worldwide should invest in reinforcing the synergy between AS and IPC highlighted during the pandemic.

\section{Letter to the editor}

The COVID-19 pandemic had a great impact on the understanding of both antimicrobial stewardship (AS) and infection prevention and control (IPC).

While AS focuses on optimizing antimicrobial use to improve the patients' outcomes and decrease the emergence of antimicrobial resistance (AMR), IPC focuses on reducing healthcare-associated infections (HAIs). The intersection between AS and IPC stands in preventing HAIs caused by multidrug-resistant organisms (MDROs) and Clostridioides difficille infections (1).

During the COVID-19 pandemic, the collaboration between IPC and AS has mitigated the shortcomings experienced by health systems worldwide, enhancing the performance of both, reinforcing the synergy between them, and increasing their preparedness in fighting other pandemics, including a more "silent" one such as AMR. In planning the post-pandemic era, health systems worldwide should invest in reinforc-
Prihvaćen/Accepted 10. 10. 2021. god.

ing the strict synergy between AS and IP highlighted during the pandemic (2).

AMR is emerging as one of the biggest public health problems of the $21^{\text {st }}$ century threatening the effective treatment of some infections caused by bacteria, parasites, viruses, and fungi that are becoming resistant to the most common antimicrobials used to treat them. AMR is a complex phenomenon developing across animal, human, and environmental habitats. Among these habitats, there is a well-known interconnected sharing of pathogens. AMR does not show any signs of decline, even if it may shift the direction.

A report published in 2014 by Lord Jim O'Neill and his team estimates an increase in deaths caused by AMR, from the current toll of 700,000 to 10 million every year by 2050 (3). This scenario will not occur if all together respond adequately to this "silent" pandemic.

The World Health Organization is on the front line against AMR and voted for a global action plan to tackle AMR at the 68th World Health Assembly in May 2015 (4).

Despite the complexity of the problem, healthcare professionals can play a significant role in combating AMR.

The burden of AMR is especially urgent for antibiotic resistance in bacteria. Antibiotic resistance is a natural phenomenon. However, it is accelerated by both the misuse and overuse of antibiotics in healthcare, as well as by poor IPC. Early antibiotic therapy to treat infections reduces morbidity and saves lives, like in cases of sepsis. However, a significant number of antibiotics prescribed in acute care facilities worldwide are either unnecessary or suboptimal concerning the choice, dose, and duration. 
Moreover, patients receiving medical care can get serious HAIs. Many HAIs are caused by MDROs such as methicillin-resistant Staphylococcus aureus (MR$\mathrm{SA}$, vancomycin-resistant enterococci (VRE), extended-spectrum-producing Enterobacteriaceae (ESBL), carbapenem-resistant Enterobacteriaceae (CRE). MDROs can spread inside and between healthcare facilities when patients are transferred from one facility to another without respecting the IPC appropriate measures. IPC initiatives work to limit the spread of MDROs in health care facilities. Effective IPC measures can reduce the need for antibiotics, prevent the spread of infections caused by MDROs and help combat the emergence of AMR. This was highlighted in the Global Action Plan on Antimicrobial Resistance (4), where one of the five strategic objectives concerns the reduction of the incidence of infections through effective IPC measures.

AS programs aim to help clinicians improve patients' outcomes by optimizing antibiotics prescribing. AS programs can increase infection cure rates and reduce:

- Treatment failures;

- C. difficile infections;

- Adverse effects;

- Antibiotic resistance;

- Hospital costs and lengths of stay.

A key strategy of AS promotes the message that antibiotics should not be prescribed for viral infections. COVID-19 is a viral respiratory tract infection and is, in most cases, self-limiting.

Bacterial secondary infections in patients with COVID-19 were not common, according to the published epidemiologic data. However, in the early stages of the pandemic, using antibiotics for the empiric treatment of secondary infections in hospitalized patients with COVID-19 was very common $(5,6)$. A meta-analysis found that $71.9 \%$ of patients hospitalized with COVID-19 before mid-April 2020 received antibiotics, although only $6.9 \%$ of these admissions were also associated with bacterial infections (6).

These results have highlighted the need for adequate use of antibiotics in managing COVID-19 and implementing AS programs around the world.

IPC has been repeatedly proved to be effective at containing the incidence of HAIs. It has been estimated that a great number of HAIs could be prevented if the evidence-based recommendations for IPC are appropriately followed in clinical practice.

The COVID-19 pandemic had an immense impact on the understanding of IPC. Around the world, people and healthcare workers implemented hand-washing techniques and social distancing, and other measures to prevent infections. In those healthcare settings that required frequent and close contact between healthcare workers and COVID-19 patients, IPC measures such as the use of personal protective equipment (PPE), hand hygiene, and cleaning and sanitization were essential to mitigate the spread of Sars-Cov-2.

However, it should be noted that the stringency of IPC measures was not possible in all settings. In those acute care facilities reaching inpatient capacity, isolation of all patients with signs of COVID-19 disease into specialized wards was not possible, and compliance with IPC measures was a real challenge (7).

IPC plays a pivotal role in containing AMR by assisting with prompt detection of MDROs and promoting compliance with standard and transmission-based precautions.

IPC should be seen as complementary to the AS initiatives as they have a shared objective and are synergistic. Where there is no transmission of infection, there is no need for antibiotic treatment, thus reducing the development of AMR.

The COVID-19 pandemic has not only created new activities for AS and IPC, but it has also created new opportunities for a bidirectional synergy. It has created new needs and increased concerns about rising rates of AMR and HAIs, both of which overlap significantly and are key focus areas for both AS and IPC. These issues have highlighted the need for new team models in which both AS and IPC are interconnected.

Healthcare system leaders should prioritize IPC and AS, as part of a vaster patient safety strategy, creating an infrastructure that can promote and disseminate the patient safety culture and best practice across the continuum of patient care. Both AS and IPC should seize all the opportunities to benefit from the expertise of each other.

The pandemic has created new opportunities for collaboration in communication and infrastructure enhancement. The infrastructure created for data access, reporting, and collaboration, even if born out of necessity, can be used in the post-pandemic era and serve as a powerful catalyst for a future synergy between IPC and AS infighting AMR.

There are numerous opportunities for IPC programs and AS programs to collaborate in sharing resources and personnel. Data review, monitoring, reporting, as well as interventions such as audit and feedback and healthcare worker education, are critical processes to both AS and IPC. Especially in resource-poor settings, integrating these activities can reduce redundant work and make for a more efficient and comprehensive workflow for both programs (2). IPC and AS programs should work together to line their programs, promote collaboration, and reduce redundant initiatives. 
AS and IPC have similarities in terms of goals, strategies, infrastructure, and metrics. The potential for collaboration has long been recognized yet underutilized. Especially in resource-poor settings, the opportunities for synergy between AS and IPC should be explored and reinforced to fight the "silent" AMR pandemic.

\section{Abbreviations}

AS - antimicrobial stewardship

IPC - infection prevention and control

AMR - antimicrobial resistance
HAIs - healthcare-associated infections

MDROs - multidrug-resistant organisms

\section{Acknowledgment}

None.

Conflict of Interests: The authors declare that there are no conflicts of interest related to this article.

Funding: None

\section{Licensing}

This work is licensed under a Creative Commons Attribution 4.0 International (CC BY 4.0) License.

\title{
Sažetak
}

\section{UPOTREBA SINERGIJE IZMEĐU ANTIMIKROBNOG UPRAVLJANJA I PREVENCIJE I KONTROLE INFEKCIJA U BORBI PROTIV OTPORNOSTI NAANTIMIKROBNE LEKOVE}

\author{
Massimo Sartelli ${ }^{1,2}$ \\ ${ }^{1}$ Department of Surgery, Macerata Hospital, Macerata, Italy \\ ${ }^{2}$ Global Alliance for Infections in Surgery
}

Pandemija KOVID-19 imala je veliki uticaj na razumevanje antimikrobnog rukovođenja (AS), kao i na prevenciju i kontrolu infekcija (IPC).

Tokom pandemije KOVID-19, saradnja između AS-a i IPC-a ublažila je nedostatke sa kojima se suočavaju zdravstveni sistemi širom sveta, poboljša-

\section{REFERENCES}

1. Manning ML, Septimus EJ, Ashley ESD, Cosgrove SE, Fakih MG, Schweon SJ, et al. Antimicrobial stewardship and infection prevention-leveraging the synergy: a position paper update. Infect Control Hosp Epidemiol. 2018; 39(4): 467-72. doi: 10.1017 /ice.2018.33.

2. Assi M, Abbas S, Nori P, Doll M, Godbout E, Bearman $\mathrm{G}$, Stevens MP. Infection prevention and antimicrobial stewardship program collaboration during the COVID-19 pandemic: a window of opportunity. Curr Infect Dis Rep. 2021; 23(10):15. doi: 10.1007/s11908-021-00759-w.

3. O'Neill J. The review on Antimicrobial resistance: tackling drug-resistant infections globally: final report and recommendations. https://amr review.org/sites/default/files/160518_Final\%20 paper_with\%20cover.pdf. Accessed on 16 September 2021. vajući njihova dostignuća, jačajući sinergiju među njima i povećavajući njihovu spremnost u borbi protiv rezistencije na antimikrobne supstance.

U planiranju postpandemijske ere, zdravstveni sistemi širom sveta treba da ulažu u jačanje sinergije između AS i IPC naglašene tokom pandemije.

4. Global action plan on antimicrobial resistance. https:// www.who.int/publications/i/item/9789241509763.Accessed on 16 September 2021.

5. Rawson TM, Moore LSP, Zhu N, Ranganathan N, Skolimowska K, Gilchrist M, et al. Bacterial and fungal coinfection in individuals with coronavirus: a rapid review to support COVID-19 antimicrobial prescribing. Clin Infect Dis. 2020; 71(9): 2459-68. doi: 10.1093/cid/ciaa530.

6. Lansbury L, Lim B, Baskaran V, Lim WS. Co-infections in people with COVID-19: a systematic review and meta-analysis. J Infect. 2020; 81(2): 266-75. doi: 10.1016/j.jinf.2020.05.046.

7. Patel PR, Weiner-Lastinger LM, Dudeck MA, Fike LV, Kuhar DT, Edwards JR, et al. Impact of COVID-19 pandemic on central-line-associated bloodstream infections during the early months of 2020, National Healthcare Safety Network. Infect Control Hosp Epidemiol. 2021 Mar 15:1-4. doi: 10.1017/ ice.2021.108. Online ahead of print.

\section{Correspondence to/Autor za korespondenciju \\ Massimo Sartelli \\ Department of Surgery, Macerata Hospital, Macerata, Italy \\ Global Alliance for Infections in Surgery \\ email: massimosartelli@gmail.com}

How to cite this article: Sartelli M. Leveraging the synergy between antimicrobial stewardship and infection prevention and control in fighting antimicrobial resistance. Sanamed.2021;16(3): 231-233 